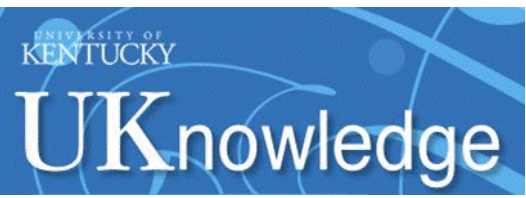

University of Kentucky

UKnowledge

8-27-2015

\title{
Who Gets Paid? Section 365(n) Royalty Payments Under "Zombie Licenses" after a Sale of IP
}

Christopher G. Bradley

University of Kentucky, cgbradley@uky.edu

Follow this and additional works at: https://uknowledge.uky.edu/law_facpub_pop

Part of the Bankruptcy Law Commons, and the Intellectual Property Law Commons

Right click to open a feedback form in a new tab to let us know how this document benefits you.

\section{Repository Citation}

Bradley, Christopher G., "Who Gets Paid? Section 365(n) Royalty Payments Under "Zombie Licenses" after a Sale of IP" (2015). Law Faculty Popular Media. 29.

https://uknowledge.uky.edu/law_facpub_pop/29

This Newsletter is brought to you for free and open access by the Law Faculty Publications at UKnowledge. It has been accepted for inclusion in Law Faculty Popular Media by an authorized administrator of UKnowledge. For more information, please contact UKnowledge@lsv.uky.edu. 
Who Gets Paid? Section 365(n) Royalty Payments Under "Zombie Licenses" after a Sale of IP

\section{Notes/Citation Information}

Christiopher G. Bradley, Who Gets Paid? Section 365(n) Royalty Payments Under "Zombie Licenses" after a Sale of IP, 12 Bankruptcy Litigation (Aug. 27, 2015). 


\title{
Bankruptcy Litigation
}

\author{
An ABI Committee Newsletter
}

Aug. 27, 2015

\section{Who Gets Paid?}

\section{Section 365(n) Royalty Payments Under "Zombie Licenses" After a Sale of IP}

\section{Christopher G. Bradley}

Taube Summers; Austin, Texas

In today's corporate bankruptcy world, a debtor's most important and valuable assets often come in the form of intellectual property (IP). Understanding the effect of bankruptcy on IP licenses is crucial not only for debtors, but also for existing licensees and for potential purchasers of IP assets.

Section 365(n) of the Bankruptcy Code provides special rules for IP licenses where the debtor is licensor - rules that depart from the familiar bankruptcy treatment of executory contracts. This article gives a brief overview of $\S 365(n)$, then provides a short analysis of a difficult but important question: When a licensee of a debtor's IP opts to retain its rights under $\S 365(n)$, who receives the stream of licensing payments in the event that the IP is sold: the buyer of the IP, or the debtor?

\section{The Basics of $\S 365(\mathrm{n})$}

Under the Bankruptcy Code's general rules governing executory contracts, a debtor in bankruptcy is given significant control to adjust its relationship with pre-bankruptcy contractual counterparties. Importantly, a debtor may choose to reject an executory contract, which has the effect of giving the (former) contractual counterparty only a claim for damages deemed to have arisen as of the petition date as a result of the debtor's rejection. A counterparty cannot force the debtor to perform any further under the rejected contract, and may receive only pennies on the dollar for the debtor's breach of contract. In the watershed case ofLubrizol Enterprises, the U.S. Court of Appeals for the Fourth Circuit held - controversially - that the "rejection" provisions of the Code mean that a licensee cannot continue to exercise its rights to the debtor's intellectual property, when those rights arise under a rejected executory contract with the debtor-licensor.[1] 
This outcome was thought by some to be exceptionally harmful to licensees of intellectual property, who often built their businesses in reliance upon a particular license or set of licenses. Lubrizol was decided in 1985, and by 1988 Congress had amended the Code to add $\S 365(n)$, which overturned Lubrizol in part. Section 365(n) provides that when a debtor/licensor rejects an executory contract, the subject of which is "intellectual property,"[2] a licensee may elect to continue acting under its license with the debtor despite the rejection. Such license rights are retained for the duration provided for in the contract, and for the term of any extensions as of right contained in the contract.

At the same time, the statute limits the licensee's power in numerous respects, balancing the licensee's right to retain its license with a number of compensating factors favoring the debtor/licensor. For one, if a licensee makes the $\S 365(n)$ election to retain its rights under the license, the licensee is not generally entitled to force the licensor to perform under the contract. Although the licensee is permitted to enforce any exclusivity provisions in the contract, the licensor is no longer required to perform any other ancillary services. Such services might include maintenance, development, support and other similar obligations. In addition, a party electing to retain rights under $\S 365(n)$ is deemed to waive any right to setoff that it might have under bankruptcy or nonbankruptcy law with respect to the contract, as well as any administrative claim for post-petition performance under the contract. Finally, the licensee is obligated to pay "all royalty payments due" under the contract. It is this "royalty" provision that is discussed below.

While, by definition, a debtor would not seek to reject a contract unless, in its business judgment, continued performance was uneconomic, a debtor often ends off in a better place after the contract has been, in essence, "rewritten" by these various parts of $\S 365(n)$. The debtor is spared any setoff arguments and administrative claims, is entitled to royalty payments, and is almost entirely relieved of its obligations to actively perform under the contract. These countervailing factors might partially or entirely bridge the gap between a profitable and unprofitable contract for the debtor - while also assuring a licensee that it will not have the rug pulled out from under it with respect to this license.[3] In sum, when $\S 365(n)$ is invoked, a contract will remain dead in some respects, but in other respects it will retain signs of life. It can lurch forward in this half-alive state for the full term of the contract. In other words, it can be thought of as a "zombie contract" or a "zombie license." 


\section{Who Gets the § 365(n) "Royalty Payments" After the Underlying IP Is Sold?}

Modern chapter 11 cases commonly center on sales of the debtor's property. Even after a debtor/licensor sells IP, of course, the licensee remains entitled to elect to retain its rights under $\S 365(n)$. And as mentioned, $\S 365(n)$ requires the licensee to make "royalty payments" due under the license. The payments form a crucial part of the scheme of $\S 365(n)$, and courts are protective of the right to payment: “'Royalty payments' owed to the debtor under $\S 365(n)$ are interpreted broadly in order to [e]nsure that the estate receives full payment when a licensee takes advantage of the debtor's intellectual property."[4]

The key question is this: Who is entitled to the "royalty payments" made by a licensee which elects to retain its license under $\S 365(n)$, when the underlying IP is sold? The answer turns out to be unclear and unsettled. On the one hand, it might seem that the purchaser of the IP should be entitled to receive payments from any license of that IP. After all, it is now the purchaser's (not the debtor's) IP that is being used pursuant to the "zombie license" granted under $\S 365(n)$. The debtor cannot perform under the contract because it no longer owns the IP, and any future licenses would have to be negotiated with the purchaser. The purchaser is, in essence, the party apparently burdened by the licensee's § 365(n) election.

In fact, courts that have addressed this issue lean in the other direction, at least under the particular factual circumstances presented to them. While the case law remains thin, courts have interpreted purchase agreements that transfer IP but exclude related licenses to leave the right to $\S 365(n)$ "royalty payments" with the debtor.[5] The right to payment, they reason, emerges from the licensing contract, rather than the IP itself. Thus, courts have reasoned, the stream of payments should flow to the debtor, not the purchaser.

More clarity may arrive in this arena with more development of the case law. In the meantime, how can one structure a transaction to ensure greater certainty in this arena?

There are no sure cures, but here are three practical approaches. First, consider specifying in a purchase agreement that, regardless of whether particular contracts are excluded from the purchase, the purchase of IP includes the right to receive any royalty payments due under $\S 365(\mathrm{n})$ that relate to any existing licenses of the IP. [6] A different approach might be to leave such rights explicitly with the debtor, and price the transaction accordingly (as the courts in the cited cases may have believed the parties did). Finally, there might also be a possibility of negotiating with a licensee "in the shadow of" $\$ 365(n)$, thereby reaching a new agreement that serves the interests of all parties going forward. 
[1] See Lubrizol Enterprises Inc. v. Richmond Metal Finishers Inc., 756 F.2d 1043 (4th Cir. 1985), cert. denied, 475 U.S. 1057 (1986). Numerous courts followed Lubrizol's analysis, which was left in place in some contexts (most notably the trademark context) by the passage of §365(n). See, e.g., Raima UK Ltd. v. Centura Software Corp. (In re Centura Software), 281 B.R. 660, 673-74 (Bankr. N.D. Cal. 2002). But it bears noting that a recent Seventh Circuit panel starkly disagreed with Lubrizol. See Sunbeam Prods. Inc. v. Chicago Amer. Mfg. LLC, 686 F.3d 372 (7th Cir. 2012); see also In re Exide Techs., 607 F.3d 957, 96667 (3d Cir. 2010) (Ambro, J., concurring).

[2] As that term is somewhat idiosyncratically defined in the Code. See 11 U.S.C. §101(35).

[3] It is important to note that this situation only applies to true executory contracts; a separate sub-set of cases deals with the sometimes-difficult question of ascertaining whether a given IP contract is executory. See, e.g., Lewis Bros. Bakeries Inc. v. Interstate Brands Corp., 751 F.3d 955 (8th Cir. 2014) (en banc); In re Exide Techs., 607 F.3d 957 (3d Cir. 2010).

[4] Microsoft Corp. v. DAK Indus. (In re DAK Indus.), 66 F.3d 1091, 1096 n.3 (9th Cir. 1995).

[5] See Schlumberger Res. Mgmt. Servs. Inc. v. CellNet Data Sys. Inc., 327 F.3d 242, 247-52 (3d Cir. 2003) (holding that purchase agreement expressly "separate[d] the royalties due under the license from the intellectual property"); In re Crumbs Bake Shop Inc., 522 B.R. 766, 779-80 (D.N.J. 2014) (holding same as CellNet, although providing that pre-closing royalties were accounts receivable that were sold to the purchaser).

[6] While not arising in the $\S 365(n)$ context, one Delaware case, In re A.B. Dick Co., which interprets CellNet somewhat narrowly, provides some support for this approach. 338 B.R. 230 (D. Del. 2006). 